\title{
Water Consumption Relative to Body Weight
}

National Cancer Institute

\section{Source}

National Cancer Institute. Water Consumption Relative to Body Weight. NCI Thesaurus.

Code $C 90485$.

The ratio or percentage of water intake to body weight. 